\title{
Evaluasi Program Edukasi dengan Video dan Poster Terhadap Perilaku Masyarakat dalam Menghadapi COVID-19 (Preliminary Study)
}

\author{
Layalia Azka Rahmatina $^{1}$, Meira Erawati ${ }^{1 *}$ \\ ${ }^{1}$ Departemen Ilmu Keperawatan Fakultas Kedokteran Universitas Diponegoro, Semarang, Indonesia \\ meiraerawati@gmail.com
}

\begin{abstract}
Introduction: The Indonesian government has issued public health protocols to deal with the corona virus disease 19 (COVID-19). In fact, this rule has been violated by many people. Health education through BARONA program may increase public understanding of disease so that their behavior will change. The purpose of this study was to evaluate the effect of providing education with videos and posters on people's behavior in dealing with COVID-19.

Methods: This study was a preliminary study involving twenty adults selected using a purposive sampling in a residential area. Respondents were given health education using posters and videos, then counted the number of respondents who showed health behavior before and after education. The data are then displayed in the frequency distribution table.

Results: The results of this study illustrate that there is an increase in the number of respondents who show the behavior of washing hands and wearing masks while traveling. Whereas in the behavior of traveling and keeping a distance from other people, there was no change.

Conclusion: Health education using posters and videos can change people's behavior in dealing with COVID-19..
\end{abstract}

Keywords: COVID-19, Education, Behavior.

\begin{abstract}
Abstrak
Pendahuluan: Pemerintah Indonesia telah menetapkan protokol kesehatan dalam mengatasi pandemi corona virus disease 19 (COVID-19), namun peraturan ini banyak dilanggar oleh masyarakat. Program BARONA diharapkan dapat mengubah perilaku adalah dengan meningkatkan pemahaman masyarakat melalui media yang mudah diterima oleh masyarakat. Tujuan penelitian ini adalah mengevaluasi edukasi dengan video dan poster terhadap perilaku masyarakat dalam menghadapi COVID-19.

Metode: Penelitian ini merupakan penelitian pendahuluan (preliminary study) dalam satu kawasan pemukiman. Responden sejumlah dua puluh orang dewasa yang dipilih dengan purposive sampling dan diberi edukasi kesehatan menggnakan media poster dan video, kemudian dilakukan penghitungan jumlah responden yang menunjukkan perilaku kesehatan sebelum dan setelah edukasi. Data yang didapat, selanjutnya ditampilkan dalam tabel distribusi frekuensi.

Hasil: Hasil penelitian ini menggambarkan terjadi peningkatan jumlah responden yang menunjukkan perilaku mencuci tangan dan menggunakan masker di saat bepergian. Sedangkan pada perilaku bepergian dan menjaga jarak dengan orang lain, tidak terdapat perubahan.

Kesimpuan: Edukasi kesehatan menggunakan poster dan video dapat merubah perilaku masyarakat ke arah yang lebih sehat dalam menghadapi COVID-19.
\end{abstract}

Kata kunci: COVID-19, Edukasi, Perilaku. 


\section{PENDAHULUAN}

Suatu penyakit baru yang menyerang saluran pernapasan dengan gejala seperti sesak napas, batuk kering, dan pusing, serta beberapa keluhan pada pencernaan ditemukan di akhir Desember 2019 di kota Wuhan, Provinsi Hubei, China (Wu, Chen, \& Chan, 2020). Artikel lain menyebutkan bahwa gejala yang sering muncul pada penyakit ini adalah demam, batuk, kelelahan, radang paru-paru, dan dispnea, serta terdapat gejala lain yang lebih jarang muncul yaitu sakit kepala, diare, hemoptisis, pilek, dan batuk berdahak. Penyakit ini disebabkan oleh novel betacoronavirus (Sars-CoV-2) yang identik dengan beta-coronavirus pada kelelawar (Adhikari et al., 2020). Penyakit ini selanjutya disebut dengan Corona Virus Disease atau disingkat COVID-19 (Kim, Jeong, Kim, Kim, \& Lee, 2020).

Studi terbaru menunjukkan bahwa COVID-19 mampu menular dari manusia ke manusia melalui kontak dekat. (Adhikari et al., 2020). Penelitian lain menyebutkan juga bahwa COVID-19 ini dapat menular melalui droplet (Kim et al., 2020; Law, Leung, \& Xu, 2020). Masa inkubasi virus ini adalah sekitar 2-14 hari, dengan rata-rata 7 hari. Pasien yang terkonfirmasi positif COVID-19 rata-rata berada pada kisaran usia antara 25 hingga 89 tahun, dan mayoritas berusia antara 35 hingga 55 tahun. Kasus yang teridentifikasi pada anak-anak dan bayi lebih sedikit dibanding pada usia dewasa hingga lansia. Populasi yang diduga paling berisiko tertular COVID-19 adalah orang-orang dengan fungsi kekebalan yang buruk seperti orang tua dan orang yang memiliki gangguan fungsi ginjal dan hati. Pada akhir bulan Januari 2020, wabah ini telah menyebar ke 19 negara lain dengan kematian mencapai 213 kasus (Adhikari et al., 2020).
Penyebaran COVID-19 di dunia mulai tidak terkendali. Terhitung hingga 20 Maret 2020, 178 negara di seluruh dunia melaporkan adanya kasus COVID-19 di negaranya dengan total kasus yang terkonfirmasi sebanyak 234.073 kasus dan kematian sebanyak 9840 kasus (Law et al., 2020). Tidak terkecuali di Indonesia. Kasus terkonfirmasi positif COVID-19 di Indonesia terus bertambah. Terhitung hingga tanggal 2 Juni 2020, kasus positif COVID-19 di Indonesia mencapai 27.549 kasus dengan angka kematian 1.663 kasus (Kementerian Kesehatan Republik Indonesia, 2020). Di Jawa Tengah sendiri kasus positif COVID-19 selalu bertambah dan belum menunjukkan adanya penurunan kurva, yaitu sebanyak 1432 kasus positif dan 100 kasus kematian. Sedangkan di kota Semarang sendiri mencapai 127 kasus positif COVID-19 (Dinas Kesehatan Provinsi Jawa Tengah, 2020).

Masyarakat yang berusia lanjut dan/atau yang memiliki penyakit pemberat, seperti kanker, sirosis, hipertensi, penyakit jantung koroner, diabetes mellitus, maupun Parkinson lebih rentan meninggal karena penyakit COVID-19 ini. Hingga hari ini belum ditemukan vaksin yang bisa digunakan untuk mengatasi wabah COVID-19 ini. Obat dan perawatan yang digunakan pun hanya mampu untuk mengurangi gejala serta membantu klien tetap hidup, seperti penggunaan ventilator mekanik, tanpa efek menghilangkan atau mematikan virus (Adhikari et al., 2020).

Pemerintah Indonesia telah menetapkan beberapa peraturan baru dalam menangani pandemi COVID-19 ini, antara lain Pembatasan Sosial Berskala Besar (PSBB), Work From Home (WFH), sekolah atau kuliah secara daring, larangan mudik, dan protokol kesehatan untuk 
mencegah penularan COVID-19, namun hal ini masih belum sepenuhnya dipatuhi oleh masyarakat Indonesia. (Buana, 2020).

Adanya kesempatan WFH maupun sekolah secara daring ini telah disalahgunakan untuk berlibur atau bahkan mudik lebih cepat oleh masyarakat. Selain itu himbauan untuk menerapkan physical maupun social distancing pun turut dilanggar (Buana, 2020). Perilaku yang kurang tepat, bahkan cenderung meremehkan pandemi ini cukup meresahkan karena dapat menyebarkan COVID-19 lebih luas lagi. Perilaku merupakan salah satu faktor yang mempengaruhi derajat kesehatan seseorang. Perilaku seseorang dapat dipengaruhi oleh sikap dalam proses pengambilan keputusan secara teliti dan beralasan. Cara untuk mengubah perilaku seseorang diantaranya dapat dilakukan dengan mengubah sikapnya. Tindakan preventif seperti pemberian edukasi dibutuhkan untuk menyadarkan masyarakat akan pentingnya menerapkan sikap hidup bersih dan sehat agar tidak tertular penyakit ini (Bili, Telly, \& Tanaem, 2019).

Pemberian edukasi telah terbukti mampu mengubah perilaku serta meningkatkan kesadaran masyarakat dalam mengontrol kesehatan. Edukasi menjadi kontribusi yang sangat penting karena dapat digunakan untuk mengatasi ancaman COVID-19 ini pada tingkatan yang berbeda. Kontribusi pada tingkat bawah berfokus pada perubahan perilaku dan manajemen penyakit tiap individu. Kontribusi pada tingkat tengah melalui intervensi yang mempengaruhi kelompok, seperti pendidikan kesehatan secara berkelompok. Sedangkan kontribusi pada tingkat atas berfokus pada pemberian informasi tentang kebijakan yang dapat mempengaruhi populasi (Broucke, 2020).
Salah satu media pendidikan yang sering digunakan untuk mengedukasi masyarakat adalah poster. Bentuk poster yang sederhana, menyajikan satu ide dan untuk mencapai satu tujuan pokok, berwarna, memiliki slogan khusus, serta tulisan yang jelas dan bervariasi dapat mempermudah dan mempercepat audiens menangkap pesan yang disajikan. (Harsismanto, Oktavidiati, \& Astuti, 2019). Selain poster, media edukasi yang juga sering digunakan untuk mengedukasi masyarakat adalah video. Media ini menggabungan dari dua jenis media yang dapat merangsang pikiran, perasaan, perhatian, kreativitas dan inovatif serta memberikan pengalaman langsung kepada audiens. Proses pembelajaran dengan melibatkan lebih dari satu indera akan lebih mudah diterima dan diingat oleh audiens (Bili et al., 2019).

Di Indonesia data tentang angka kejadian COVID-19 ini sudah secara rutin dilakukan pembaharuan. Namun penelitian tentang perilaku penerapan protokol kesehatan tentang pencegahan perluasan penyebaran penyakit masih kurang. Terlebih lagi gambaran perilaku masyarakat masih terkesan tidak mengindahkan protokol kesehatan di masa pandemi. Perilaku ini tentu perlu diluruskan, agar penyebaran infeksi COVID-19 ini tidak semakin meluas. Salah satu upaya yang bisa dilakukan untuk mengubah perilaku adalah dengan meningkatkan pemahaman masyarakat melalui program edukasi BARONA dengan media yang mudah diterima oleh masyarakat. Berdasarkan pertimbangan tersebut, maka tujuan dari penelitian ini adalah untuk melakukan evaluasi program sebagai kajian awal tentang efek edukasi dengan menggunakan poster dan video terhadap perilaku masyarakat dalam menghadapi COVID-19. 


\section{METODE}

Penelitian ini merupakan penelitian pendahuluan (preliminary study), yang melibatkan 20 orang dewasa dalam satu kawasan pemukiman yang dipilih dengan metode purposive sampling. Setiap responden telah menyatakan bersedia untuk terlibat dalam kegiatan penelitian secara verbal, setelah mendapatkan informasi dari peneliti (verbal informed consent).

Kegiatan penelitian ini terintegrasi dalam program Balai Edukasi Corona (BARONA) yang merupakan salah satu program dari Kementerian Pendidikan dan Kebudayaan dalam menangani COVID-19. Kegiatan ini bertujuan untuk memberikan edukasi kepada masyarakat dan diharapkan mampu meningkatkan pengetahuan masyarakat mengenai penyakit COVID-19 sehingga terjadi perubahan perilaku untuk menerapkan protokol kesehatan guna mencegah penularan dan memutus rantai penyebaran COVID-19.

Penelitian ini dilaksanakan dalam kurun waktu 14 hari, terhitung mulai tanggal 25-26 Mei 2020 hingga hingga tanggal 7-8 Juni 2020. Adapun proses dari kegiatan ini yaitu:

1. Persamaan persepsi yang dipandu oleh Pilot Project Team Promotor-Evaluator Balai Erona (21-22 Mei 2020)

2. Pengajuan ijin kegiatan kepada pemangku kebijakan setempat (Ketua RT)

3. Melakukan wawancara awal tentang perilaku yang dilakukan selama pandemi COVID-19 ini kepada responden (pre-test). Dilaksanakan pada tanggal 25 Mei 2020. Perilaku yang ditanyakan kepada responden antara lain kegiatan keluar rumah, penggunaan masker, social dan physical distancing, kebiasaan mencuci tangan menggunakan sabun/hand sanitizer, dan membersihkan diri usai bepergian. Pengambilan data menggunakan panduan wawancara dengan kisi-kisi pertanyaan yang telah ditetapkan oleh pengelola program BARONA, sehingga tidak ada proses uji validitas dan reliabilitas instrumen penelitian.

4. Pemantauan kesehatan responden yang dilakukan melalui aplikasi whatsApp dengan menggunakan telepon pintar. Kegiatan ini dilaksanakan selama 8 hari, dimulai tanggal 26 sampai 31 Mei 2020.

5. Memberikan intervensi (edukasi) kepada responden menggunakan media poster dan video animasi terkait COVID-19 yang dibuat oleh Tim VideoAnimator dari Balai Erona. Materi edukasi yang berikan kepada responden antara lain mengenai anjuran menggunakan masker, menjaga kebersihan diri dengan cuci tangan menggunakan sabun/handsanitizer, tidak bepergian selama pandemi, pentingnya menjaga jarak, dan kapan waktunya memeriksakan diri saat sakit selama pandemi. Kegiatan ini dilaksanakan selama 6 hari, dimulai tanggal 1 - 6 Juni 2020.

6. Melakukan wawancara evaluasi (posttest) kepada responden tentang perilaku masyarakat dalam menghadapi pandemi COVID-19 di hari ke 14. Kegiatan ini dilaksanakan pada tanggal 7 Mei 2020.

Data yang didapat, kemudian ditampilkan dalam tabel distribusi frekuensi sederhana.

\section{HASIL}

Setelah dilakukan evaluasi pada efek intervensi edukasi terhadap perilaku responden, diperoleh hasil yang menunjukkan bahwa terjadi peningkatan jumlah responden yang menunjukkan perilaku mencuci tangan dan menggunakan masker di saat bepergian. Sedangkan pada 
Tabel 1. Perubahan perilaku masyarakat sebelum (pre-test) dan sesudah pemberian edukasi (post-test) $(\mathrm{n}=20)$.

\begin{tabular}{|c|c|c|c|c|c|c|}
\hline \multirow[b]{2}{*}{ Perilaku } & \multicolumn{3}{|c|}{ Pre-test } & \multicolumn{3}{|c|}{ Post-test } \\
\hline & $\begin{array}{l}\text { Frekuensi } \\
\quad(\mathbf{n})\end{array}$ & $\begin{array}{l}\text { Persentase } \\
\quad(\%)\end{array}$ & $\begin{array}{c}\text { Jumlah } \\
\text { (Persentase) }\end{array}$ & $\begin{array}{l}\text { Frekuensi } \\
\quad(\mathbf{n})\end{array}$ & $\begin{array}{l}\text { Persentase } \\
\quad(\%)\end{array}$ & $\begin{array}{c}\text { Jumlah } \\
\text { (Persentase) }\end{array}$ \\
\hline \multicolumn{7}{|c|}{ Bepergian Saat Pandemi } \\
\hline $\mathrm{Ya}$ & 18 & 90 & \multirow{2}{*}{$20(100 \%)$} & 18 & 90 & \multirow{2}{*}{$20(100 \%)$} \\
\hline Tidak & 2 & 10 & & 2 & 10 & \\
\hline \multicolumn{7}{|c|}{ Tujuan Bepergian } \\
\hline Pekerjaan & 3 & 15 & \multirow{6}{*}{$20(100 \%)$} & 3 & 15 & \multirow{6}{*}{$20(100 \%)$} \\
\hline Membeli & 11 & 55 & & 11 & 55 & \\
\hline Kebutuhan & & & & & & \\
\hline Rekreasi & 1 & 5 & & 1 & 5 & \\
\hline Lainnya & 3 & 15 & & 3 & 15 & \\
\hline Tidak Bepergian & 2 & 10 & & 2 & 10 & \\
\hline \multicolumn{7}{|c|}{ Menjaga Jarak Saat Bepergian } \\
\hline Ya & 18 & 90 & \multirow{3}{*}{$20(100 \%)$} & 18 & 90 & \multirow{3}{*}{$20(100 \%)$} \\
\hline Tidak & 0 & 0 & & 0 & 0 & \\
\hline Tidak Bepergian & 2 & 10 & & 2 & 10 & \\
\hline \multicolumn{7}{|c|}{$\begin{array}{l}\text { Menjaga kebersihan diri dengan mencuci tangan menggunakan sabun usia bepergian atau } \\
\text { menggunakan antiseptik }\end{array}$} \\
\hline Ya selalu & 16 & 80 & \multirow{4}{*}{$20(100 \%)$} & 18 & 90 & \multirow{4}{*}{$20(100 \%)$} \\
\hline Kadang-kadang & 2 & 10 & & 0 & 0 & \\
\hline Tidak & 0 & 0 & & 0 & 0 & \\
\hline Tidak bepergian & 2 & 10 & & 2 & 10 & \\
\hline \multicolumn{7}{|c|}{ Menggunakan masker setiap kali bepergian keluar rumah } \\
\hline Ya selalu & 13 & 65 & \multirow{4}{*}{$20(100 \%)$} & 16 & 80 & \multirow{4}{*}{$20(100 \%)$} \\
\hline Kadang-kadang & 5 & 25 & & 2 & 10 & \\
\hline Tidak & 0 & 0 & & 0 & 0 & \\
\hline Tidak bepergian & 2 & 10 & & 2 & 10 & \\
\hline
\end{tabular}

perilaku bepergian dan menjaga jarak dengan orang lain tidak ada perubahan.

Perubahan perilaku masyarakat sebelum (pre-test) dan sesudah pemberian edukasi (post-test) disajikan pada tabel 1.

\section{PEMBAHASAN}

Hasil penelitian menunjukkan bahwa setelah dilaksanakan program edukasi dengan menggunakan media poster dan video, terjadi peningkatan jumlah responden yang melakukan cuci tangan dan menggunakan masker saat bepergian di masa pandemi. Hasil penelitian ini sejalan dengan hasil penelitian yang dilakukan di China, yang menunjukkan bahwa pendidikan kesehatan berkontribusi terhadap peningkatan pengetahuan dan perilaku terhadap pencegahan penyakit infeksi (Wang et al., 2018). Pemberian edukasi kesehatan memiliki tujuan utama yaitu terjadinya perubahan perilaku dengan memperbaiki pengetahuan (kognitif), sikap, serta praktik (mendapatkan akses informasi kesehatan, mempergunakan informasi) sehingga dapat digunakan untuk meningkatkan atau mempertahankan kesehatannya. Selain itu, salah satu faktor pembentukan sikap seseorang adalah komunikasi sosial yang berupa informasi 
yang diterima oleh individu tersebut. (Harsismanto et al., 2019). Perubahan perilaku yang dialami masyarakat dipengaruhi karena adanya peningkatan pengetahuan mengenai manfaat dan cara merubah perilakunya (Buana, 2020).

Penelitian ini melibatkan 20 orang dewasa sebagai responden. Sebagaimana penelitian terdahulu, perubahan perilaku orang dewasa sebagai hasil dari pelaksanaan edukasi kesehatan dipengaruhi oleh beberapa faktor, antara lain tingkat pendidikan, usia, jenis kelamin, status perkawinan, dan kecukupan pengeluaran, (Çaylan, Yayla, Öztora, \& Dağdeviren, 2017; Oo, Soe, \& Lwin, 2015). Terbentuknya perilaku baru, terutama pada orang dewasa, diawali dari segi kognitifnya. Individu harus mengetahui terlebih dahulu materi atau objek di luar sebagai stimulus, sehingga menimbulkan pengetahuan baru pada objek tersebut. Akhirnya rangsangan tersebut diketahui dan disadari sepenuhnya sehingga dapat menimbulkan respon lebih jauh lagi, yaitu berupa tindakan (action) terhadap stimulus atau objek tersebut (Herman, Citrakesumasari, Hidayanti, Jafar, \& Virani, 2020).

Hasil penelitian ini menunjukkan terjadinya peningkatan jumlah responden yang mencuci tangan dan menggunakan masker saat bepergian di masa pandemi setelah dilakukannya edukasi kesehatan. Hasil penelitian ini sejalan dengan penelitian sebelumnya yang membuktikan bahwa pendidikan kesehatan tentang mencuci tangan efektif meningkatkan kebiasaan mencuci tangan pada responden (Nour-Eldein \& Eldahshan, 2015). Sebuah literature review menunjukkan bahwa peningkatan perilaku mencuci tangan setelah dilakukan edukasi bervariasi mulai dari 5\% sampai 20\% (Quilab, Johnson, Schadt, \& Mitchell, 2019).
Penelitian ini menggunakan poster dan video sebagai media edukasi kesehatan kepada resoponden. Pemilihan media intervensi pada penelitian ini sejalan dengan penelitian sebelumnya yang dilakukan di Thailand, yang menjukkan bahwa edukasi kesehatan dengan menggunakan video demonstrasi, secara bermakna berdampak pada penerimaan, pengetahuan dan perilaku masyarakat (Worasathit, Wattana, Okanurak, Songthap, Dhitavat, \& Pitisuttithum, 2015). Pemilihan media berupa poster dan video didasari pada pemikiran bahwa panca indera yang paling banyak menyalurkan informasi ke otak adalah mata (kurang lebih 75\%-87\%), sedangkan 13\%$25 \%$ lainnya diperoleh dan disalurkan melalui panca indera yang lain (Herman, Citrakesumasari, Hidayanti, Jafar, \& Virani, 2020). Informasi juga akan semakin mudah diterima dan diingat jika menggunakan lebih dari satu indera (Bili et al., 2019).

\section{KETERBATASAN PENELITIAN}

Penelitian ini merupakan penelitian pendahuluan (preliminary study) yang melibatkan responden dalam jumlah kecil. Wawancara dilakukan dengan kisi-kisi pertanyaan yang tercantum dalam program BARONA sehingga tidak ada uji validitas dan reliabilitas instrumen penelitian. Secara statistik, nilai kemaknaan hasil tidak bisa ditampilkan.

\section{KESIMPULAN DAN SARAN}

Pemberian edukasi BARONA menggunakan media video dan poster efektif untuk mengubah perilaku masyarakat dalam menghadapi pandemi Covid- 19 ini. Pendidikan kesehatan tentang protokol kesehatan perlu diberikan dengan media interaktif pada masyarakat agar perilaku sehat diterapkan dalam kehidupan sehari-hari. Penelitian ini perlu 
ditindaklanjuti dengan melibatkan jumlah sampel yang lebih banyak dengan menggunakan kuesioner yang telah teruji validitas dan reliabilitasnya, serta perlu dilakukan pengolahan data statistik yang lebih kompleks.

\section{DAFTAR PUSTAKA}

Adhikari, S. P., Meng, S., Wu, Y., Mao, Y., Ye, R., Wang, Q., .... Zhou, H. (2020). Epidemiology, causes, clinical manifestation and diagnosis, prevention and control of Coronavirus Disease (COVID-19) during the early outbreak period: A scoping review. Infectious Diseases of Poverty, 9(29), $1-12$.

Bili, S., Telly, M., \& Tanaem, N. F. D. (2019). Pengaruh pendidikan kesehatan dengan audio visual terhadap perilaku pencegahan penularan pada keluarga dengan tuberkulosis paru di wilayah kerja Puskesmas Sikumana. CHMK Health Journal, 3(2), 20-26.

Broucke, S. Van den. (2020). Why health promotion matters to the COVID19 pandemic, and vice versa. Editorial Oxford Press, 35, 181186. doi: 10.1093/heapro/daaa042

Buana, D. R. (2020). Analisis perilaku masyarakat Indonesia dalam menghadapi pandemi virus Corona (COVID-19) dan kiat menjaga kesejahteraan jiwa. Jurnal Sosial \& Budaya Syar-I, 7(3), 217-226.

Çaylan, A., Yayla, K., Öztora, S., \& Dağdeviren, H. N. (2017). Assessing health literacy, the factors affecting it and their relation to some health behaviors among adults. Biomedical Research, 28 (15): 6803-6807
Dinas Kesehatan Provinsi Jawa Tengah. (2020). Sebaran kasus COVID-19 di Jawa Tengah. Diperoleh dari https://corona.jatengprov.go.id/

Harsismanto, Oktavidiati, E., \& Astuti, D. (2019). Pengaruh pendidikan kesehatan media video dan poster terhadap pengetahuan dan sikap anak dalam pencegahan penyakit diare. Jurnal Kesmas Asclepius, 1(1), 75-85. doi: 10.31539/jka.v1i1.747

Herman, Citrakesumasari, Hidayanti, H., Jafar, N., \& Virani, D. (2020). Pengaruh edukasi gizi menggunakan leaflet Kemenkes terhadap perilaku konsumsi sayur dan buah pada remaja di SMA Negeri 10 Makassar. JGMI: The Journal of Indonesian Community Nutrition, 9(1), 39-50.

Kementerian Kesehatan Republik Indonesia. (2020). Situasi virus Covid-19 di Indonesia. Diperoleh June 2, 2020， dari https://covid19.go.id/

Kim, Y. J., Jeong, Y. J., Kim, S. H., Kim, Y. J., \& Lee, S. Y. (2020). Preparedness for COVID-19 infection prevention in Korea: Single-center experience. Journal of Hospital Infection: Pre-Roof Journal, 1-7. doi: 10.1016/j.jhin.2020.04.018

Law, S., Leung, A. W., \& Xu, C. (2020). Severe Acute Respiratory Syndrome (SARS) and Coronavirus Disease-2019 (COVID-19): From causes to preventions in Hong Kong. International Journal of Infectious Diseases, 94, 156-163. doi: 10.1016/j.ijid.2020.03.059 
Nour-Eldein, H. \& Eldahshan, N. A. (2015). The effectiveness of hand hygiene education intervention for medical students in primary care settings, Ismailia City, Egypt. Middle East Journal Of Family Medicine. 13, 32-40. doi: 10.5742/MEMFM.2015.92667

Oo, W. M., Soe, P. P., \& Lwin, K. T. (2015). Status and determinants of health literacy: a study among adult population in selected areas of Myanmar. International Journal of Community Medicine and Public Health. 2(3), 318-322. doi: $10.18203 / 2394-$ 6040.ijcmph20150489

Quilab, M. T., Johnson, S., Schadt, C., \& Mitchell, A. (2019). The effect of education on improving hand hygiene compliance among healthcare workers. Hospice \& Palliative Medicine International Journal. 3(2):66-71
Wang, M., Han, X., Fang, H., Xu, C., Lin, X., Xia, S., ... Tao, H. (2018). Impact of health education on knowledge and behaviors toward infectious diseases among students in Gansu Province, China. BioMed Research International. doi: $10.1155 / 2018 / 6397340$

Worasathit, R., Wattana, W., Okanurak, K., Songthap, A., Dhitavat, J., \& Pitisuttithum, P. (2015). Health education and factors influencing acceptance of and willingness to pay for influenza vaccination among older adults. BMC Geriatrics, 15(136), 1-14. doi: 10.1186/s12877-015-0137-6

Wu, Y., Chen, C., \& Chan, Y. (2020). The outbreak of COVID-19: An overview. Journal of Chinese Medical Association, 83, 217-220. doi:

10.1097/JCMA.0000000000000270 $>\mathrm{Wu}$. 